Proc. Estonian Acad. Sci. Biol. Ecol., 2005, 54, 4, 323-330

\title{
A small annelid community (Enchytraeidae, Tubificidae, Aeolosomatidae) during meadow restoration on arable land and in a nearby well-preserved meadow
}

\author{
Jiří Schlaghamerský* and Klára Kobetičová \\ Department of Zoology and Ecology, Faculty of Science, Masaryk University, Kotlářská 2, 61137 \\ Brno, Czech Republic
}

Received 12 October 2004, in revised form 2 August 2005

\begin{abstract}
A small annelid community (Enchytraeidae, Tubificidae, Aeolosomatidae) was studied in a field experiment during meadow restoration on arable land and in a well-preserved meadow nearby. Comparison of the effect of different seed mixtures and spontaneous succession in an abandoned field revealed no significant differences, but a trend to lower densities in plots sown with regional seed mixture compared to some increase in densities with spontaneous succession and those sown with commercial seed mixture was observed. In 2003, i.e. the fifth year of the experiment, dry weather caused very low densities in all treatments as well as in the adjacent arable field. In total, 17 enchytraeid, 1 tubificid, and 2 aeolosomatid species were recorded at the experimental site. In the well-preserved meadow nearby an assemblage of similar species composition with 22 enchytraeid, 1 tubificid, and 1 aeolosomatid species was found.
\end{abstract}

Key words: Enchytraeidae, Tubificidae, Aeolosomatidae, meadow restoration, grasslands.

\section{INTRODUCTION}

Anthropogenic grasslands are one of the main ecosystems in Europe but were substantially reduced in area in the course of the 20th century due to the decreasing economic importance of pastureland and hay production. In the White Carpathians, a mountain range on the border of Moravia (the Czech Republic's eastern part) and Slovakia, pastures and hay meadows had been major types of land use with predominant hay production since the end of the 19th century. The area's natural conditions as well as its traditional ways of meadow management led to the development of grasslands particularly rich in plant species. Despite the high erosion potential of local soils (mainly Cambisols on flysch), much grass-

*Corresponding author, jiris@sci.muni.cz 
land was turned into arable land in the 1970s. The remaining ones (some 1100 ha protected in nature reserves) are of extraordinary value for nature conservation. The administration of the White Carpathians Protected Landscape Area attempts to restore species-rich meadows on some of the arable land. Within a project aimed at finding the most efficient way of meadow restoration, soil-dwelling annelids of small body size (Enchytraeidae, Tubificidae, Aeolosomatidae) were studied in experimental plots subjected to alternative treatments and in a wellpreserved traditional hay meadow nearby. The treatments were to show if and how the differing development of vegetation (based on different seed mixtures or spontaneous succession) would influence the development of the small annelid community. Compared to the initial state of an arable field an increase in the species number and changes in the species representation due to immigration of stress-intolerant species and a stronger concentration of individuals in the uppermost soil layer due to a lower amount of dead organic matter at greater depths were expected. Data from the experimental plots up to the fourth year of the experiment have already been reported (Schlaghamerský 2005, Tajovský et al. 2005). This contribution summarizes the development up to the fifth year of succession and compares the found communities with that of a well-preserved hay meadow, representing the situation aimed at. Enchytraeids have been very poorly studied in entire Moravia and the closest data from Slovakia refer to forest sites in the Little Carpathians (Kasprzak 1986). No data were available from the White Carpathians before the above-mentioned project.

\section{MATERIALS AND METHODS}

\section{The study sites}

The two sites are situated at about $2.5 \mathrm{~km}$ distance from each other in the White Carpathians, Czech Republic. The long-term mean (1951-1980) of annual temperature is $8.9^{\circ} \mathrm{C}$ and of annual precipitation $553 \mathrm{~mm}$. In 2003 the area was exposed to an extreme summer draught (annual precipitation: $364 \mathrm{~mm}$ ).

The experimental site is situated near the village of Malá Vrbka on the NE-facing slope $\left(7^{\circ}\right)$ of Výzkum hill at 380-430 $\mathrm{m}$ a.s.l. The former meadow had been turned into arable land in the 1970s. In spring 1999 it was divided into 16 plots ( $55 \mathrm{~m} \times 20 \mathrm{~m}$ ), which were ploughed, harrowed, and subsequently subjected to four different types of treatment (four plots each): (1) sowing with a regional seed mixture - RSM (dominated by Bromus erectus, Festuca rupicola, Poa angustifolia, Koeleria pyramidata, Briza media, Antoxanthum odoratum, Trifolium rubens, T. montanum, and Jacea pratensis), (2) sowing of a $5 \mathrm{~m}$ wide central strip with RSM, leaving the lateral strips to spontaneous succession, (3) sowing of a $5 \mathrm{~m}$ wide central strip with RSM and the lateral strips with a commercial seed mixture - CSM (dominated by Festuca rubra, F. pratensis, F. ovina, F. rupicula, Arrhenatherum elatius, Bromus erectus, Poa pratensis, Trisetum flavescens, and Cynosurus cristatus), and (4) abandoned field subject to spontaneous succession - AF (dominated by Taraxacum officinale, Bromus erectus, Arrhenatherum elatius, Jacea 
pratensis, Leontodon hispidus, and Plantago lanceolata). Since then, the plots have been mown annually to direct secondary succession towards a meadow. Adjacent to the experimental plots is an arable field that was partially sampled as well (under permanent crop rotation with wheat in 1999 and 2002, sunflower in 2000, maize in 2001, and barley in 2003). The soil of (silty) clay-loam texture is Luvisol or Gleyic Luvisol on loess above flysch sandstone; it is characterized by slow infiltration and rapid run-off but poor drainage. Soil organic carbon in the upper $10 \mathrm{~cm}$ ranged between $2.1 \%$ and $3.4 \%$ in the experimental plots $(2.9-3.3 \%$ in the adjacent field). Soil $\mathrm{pH}$ in the upper $10 \mathrm{~cm}$ was rather variable: $\mathrm{pH}_{\mathrm{H}_{2} \mathrm{O}}$ 5.7-7.1, $\mathrm{pH}_{\mathrm{KCl}} 4.7-6.4$ (in the adjacent field 6.5-7.3 and 5.5-6.5, respectively). For further details see Tajovský et al. (2005).

The meadow site is situated about $2.5 \mathrm{~km}$ to the southwest in the Črtoryje National Nature Reserve ( $326 \mathrm{ha}$ ). Most of the area is covered by thermophilic meadows of the association Cirsio-Brachypododion pinati (dominated by Brachypodium pinnatum and Bromus erectus); spring fen vegetation is dominated by Carex distans, Valeriana dioica, and the moss Fissidens adianthoides (Bezděčka \& Jongepier 2002). Sampling was conducted on a west-facing slope (ca. $380 \mathrm{~m}$ a.s.1.) along a gradient towards a small spring fen (elsewhere the soil was very dry and hard to sample).

\section{Sampling and sample processing}

In all the years samples at the Výzkum site were taken in May, September, and November. Soil cores of $10 \mathrm{~cm}^{2}$ surface area were taken until 2001; since 2002 a soil corer of $17 \mathrm{~cm}^{2}$ surface area was used. Limited sampling was conducted in 2000 (2-3 soil cores, 3 dates at Výzkum including the adjacent field, 2 dates at Čertoryje). In 2001 intensive sampling in one of the abandoned field plots in May and November served to establish reliable "initial" density data and to fine-tune the extraction method (Kobetičová \& Schlaghamerský 2003). Three soil cores were taken in September. At Čertoryje five soil cores were taken in September along a moisture gradient towards a small spring fen (max distance from the fen $2.5 \mathrm{~m}$ ). In 2002 and 2003 the three basic experimental treatments at the Výzkum site (AF, RSM, CSM) were sampled, taking two randomly placed soil cores in each of the four plots ( 8 soil cores per treatment). In 2003, 8 soil cores were also taken along a transect in the adjacent field on all three dates. In May 2003 another 16 soil cores were taken at Čertoryje, of those 8 in the meadow and 8 in and around a spring fen. In all cases the soil cores were subdivided into $3-\mathrm{cm}$ layers and from these small annelids were obtained by wet funnel extraction (generally $12 \mathrm{~h}$ of cold extraction followed by gradual heating up of the soil surface to $43^{\circ} \mathrm{C}$ within $4 \mathrm{~h}$ ). Specimens were kept in cold tap water, counted, and identified alive under a light microscope. Differences between numbers of individuals (on which the density calculations were based) were tested by the distribution-free ("nonparametric") Kruskal-Wallis test and subsequent (post hoc) pair-wise comparison (using Statistica for Windows 7.1; pair-wise comparison was also conducted with adjustment for ties using the Mann-Whitney U-test). 


\section{RESULTS}

Enchytraeid density data for the Výzkum site computed for the various treatments and sampling dates are given in Fig. 1 (other small annelids were found in low numbers and were not included to allow direct comparison with enchytraeid densities given by other authors). However, the shown trends are to be taken with care as the differences were in most cases not statistically significant. In 2000 similar densities ranging from 1000 to $7000 \mathrm{ind} / \mathrm{m}^{2}$ (sampling date means) were found in all treatments. In 2001 the computed mean densities in AF were 7200 (SE 1800) ind $/ \mathrm{m}^{2}$ in May and 6800 (SE 1500) ind $/ \mathrm{m}^{2}$ in November. Vertical distribution differed substantially between these sampling dates $(10 \%$ and $55 \%$ of individuals present in the upper $3 \mathrm{~cm}$ of soil respectively). The density of 24000 (SE 6500) ind $/ \mathrm{m}^{2}$ for September was the highest found throughout the study. However, it was based on three soil cores only (intensive sampling was limited to May and November) and thus the difference to the other computed densities was not significant. The annual density for 2001 based on these data was higher than the annual densities found in 2003 (highly significant) but not significantly higher than those in 2002. In 2002 the mean annual densities in the three studied treatments ranged between 2600 (SE 1200) ind $/ \mathrm{m}^{2}$ and 8000 (SE 3600) ind $/ \mathrm{m}^{2}$. The highest density of 12000 (SE 5400) ind $/ \mathrm{m}^{2}$ was found in the CSM treatment in May

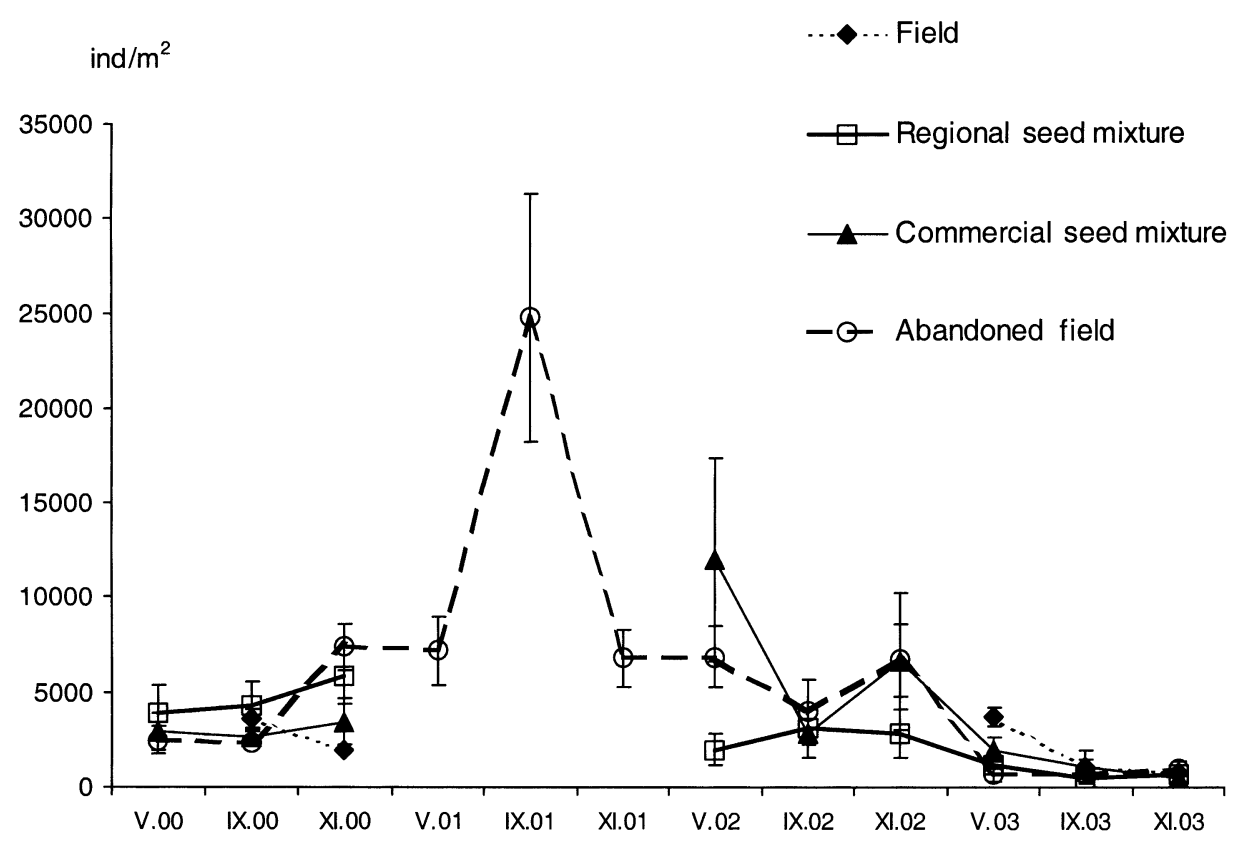

Fig. 1. Mean enchytraeid densities ( \pm standard error of the mean) in the meadow restoration treatments and an arable field at the Výzkum site. 
(difference not significant). Vertical distribution differed between dates and treatments: Enchytraeids in the AF were concentrated in the upper $3 \mathrm{~cm}$ while highest densities in the lower layers were reached in RSM (for details see Schlaghamerský 2005). In 2003 very low densities were encountered, ranging in the experimental plots between 400 and $2000 \mathrm{ind} / \mathrm{m}^{2}$ per treatment and sampling date. The mean annual densities based on the three sampling dates were significantly lower in 2003 than in 2002 in two of the three treatments studied in both years, i.e. $\operatorname{CSM}(p=0.029)$ and AF $(p=0.0001)$. Most enchytraeids $(\geq 50 \%)$ were found in the 3-6 cm layer. Densities up to 3700 (SE 1500) ind $/ \mathrm{m}^{2}$ were found on the adjacent field. There only $23 \%$ of the individuals were present in the upper $6 \mathrm{~cm}$ of soil. In total, 17 enchytraeid, 1 tubificid, and 2 aeolosomatid species were recorded at the Výzkum site (Table 1). The highest number was found in AF (19 species), the lowest in the arable field (8 species).

The most reliable density data for the enchytraeid assemblage on the Čertoryje site are those from May 2003 (those from earlier samplings would be based on sample units taken along a moisture gradient), when some 5400 (SE 2000) ind $/ \mathrm{m}^{2}$ were found in the meadow and 1300 (SE 700) ind $/ \mathrm{m}^{2}$ in and around the spring fen. In the meadow $54 \%$ of the individuals $(n=99)$ were found at a depth of $6-12 \mathrm{~cm}$ on this date. In total 22 enchytraeid, 1 tubificid, and 1 aeolosomatid species were found at Črtoryje (Table 1). The species composition was similar to that at Výzkum hill but included several additional species, none of which was restricted to the spring fen.

Twelve enchytraeid species had not been reported from the Czech Republic before the studies at Výzkum and Čertoryje (underlined in Table 1); however, the identity of some requires further investigation.

\section{DISCUSSION}

Although the density data for 2000 are based on very small samples and those for 2001 reflect the conditions in a single abandoned field plot only, data up to 2002 show a trend of increasing densities in the commercial seed and abandoned field treatments. However, density data for single dates or annual data based on few sampling dates can be misleading when interpreting differences between years or sites and treatments. All the densities found are well within the range reported from other grasslands and fields; however, also much higher annual values (up to $130000 \mathrm{ind} / \mathrm{m}^{2}$ ) have been found both in acidic and alkaline grassland soils (Didden 1993). In 2003 densities remained extremely low on all dates and in all treatments at Výzkum hill, including the adjacent field. The reason was rather obvious, as the year was extremely dry. Thus the quality of data on vertical distribution or community structure for this year was very poor and these data are not presented (corresponding data for the previous years see Schlaghamerský 2005). Also the attempt to compare the experimental treatments with the adjacent arable field was hampered by the unfavourable weather conditions in 2003. How- 


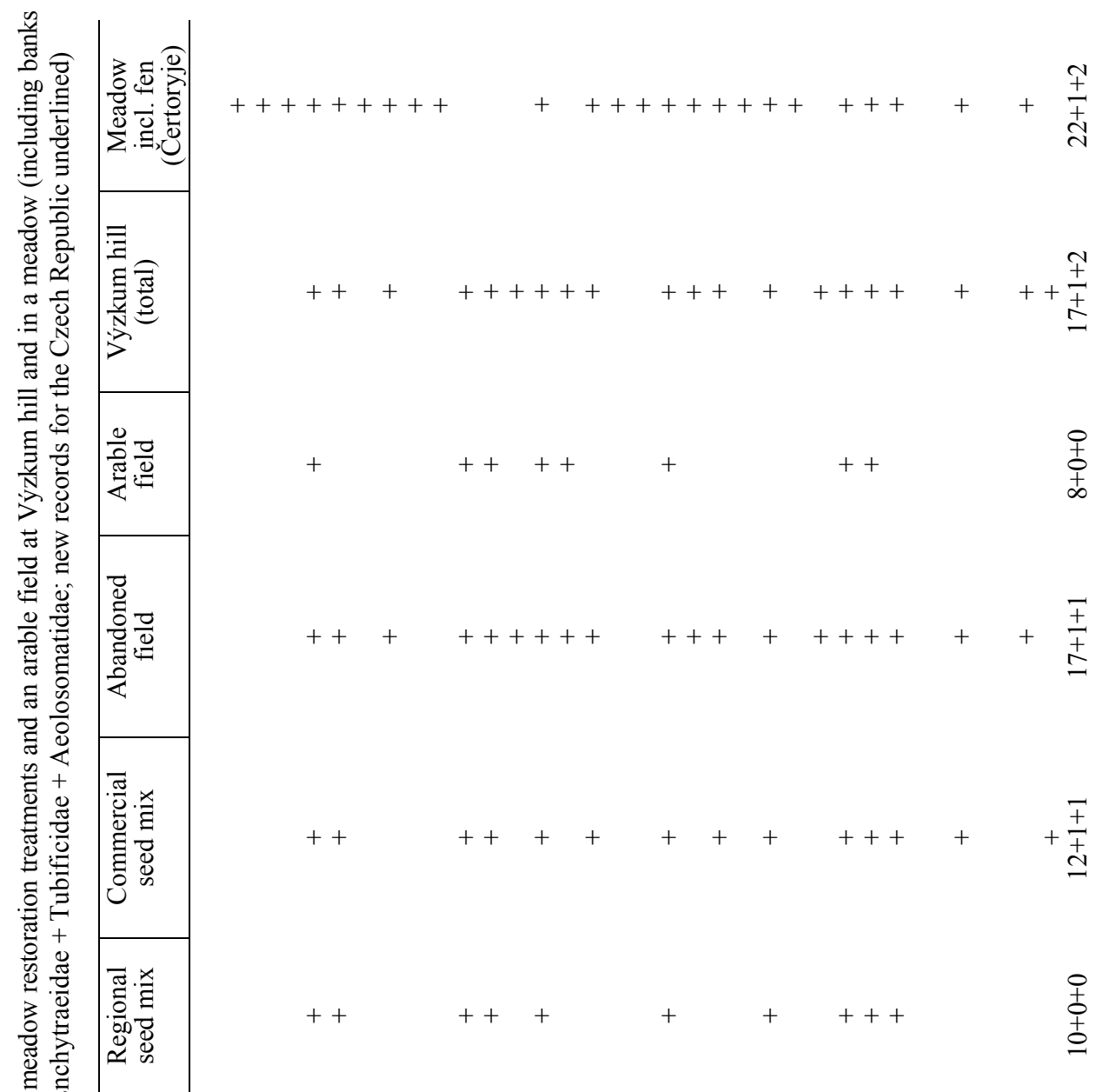
वूँ

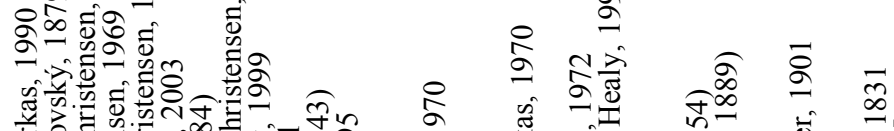

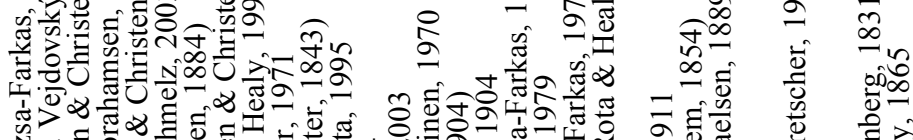

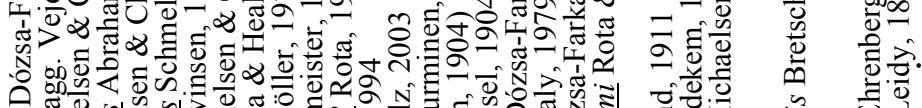

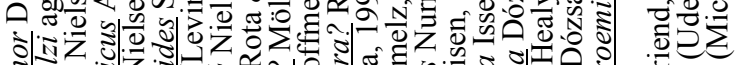

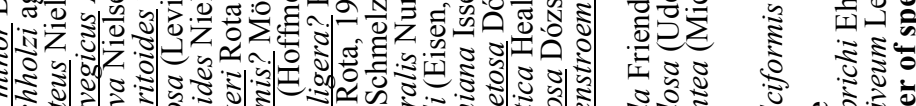

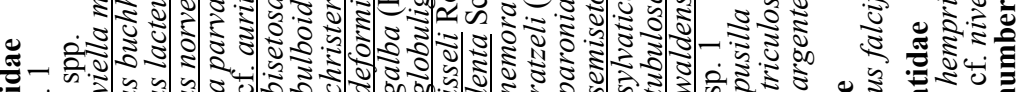

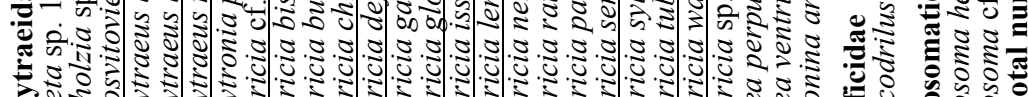

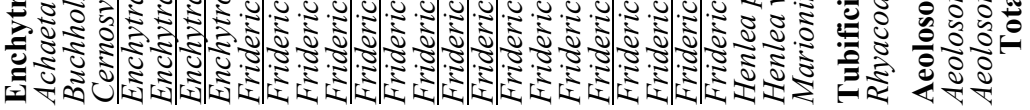


ever, it is noteworthy that enchytraeid densities were not lower in the arable soil than in the permanently vegetated plots. For the well-preserved meadow at Certoryje only the density value for May 2003 is suitable for comparison (not being based on sample units taken in places of very different soil moisture; e.g. the corresponding value for the spring fen was decreased by zero counts from cores of anoxic fen sediments). Considering the corresponding data from the Výzkum site, the density at Čertoryje seems somewhat higher, although previous samplings had indicated very low densities at this meadow site.

The rather species-rich small annelid community encountered at Výzkum is probably the consequence of the variable but generally not too high soil acidity, with microsites providing favourable conditions for different species. Apparent differences in the species richness of treatments have to be handled with care, as they might be an artefact of differing sampling intensity. However, the list for the entire site can be considered to reflect well the community present. Basically all species are indicators of slightly acidic to slightly alkaline soils, Marionina argentea also of wet conditions (Graefe \& Schmelz 1999). It is rather surprising that the site with its high variation of soil moisture (from a semi-liquid stage to a driedup, extremely compact stage) does not present an extreme habitat to enchytraeids. This is underlined by the occurrence of Rhyacodrilus falciformis (Tubificidae) and Aeolosoma spp. (Aeolosomatidae), generally considered aquatic (although there are some records from terrestrial habitats). In terrestrial habitats $R$. falciformis is considered to indicate slightly acid to slightly alkaline, moist soils in damp, but not wet habitats (Graefe \& Schmelz 1999). The author is not aware of any previous records of Aeolosoma spp. from arable or grassland soils but they might have been neglected in studies on potworms. The community at Čertoryje seems somewhat richer in species (higher number based on lower sampling intensity) and generally rich for a grassland. One reason of the high number of species might be also the variable moisture conditions along the sampled gradient. However, the site's assemblage was not very different from that at Výzkum. The presence of C. minor at Čertoryje was probably due to the permanently wet conditions in the vicinity of the spring fen, but the species was also found in the meadow $2.5 \mathrm{~m}$ away from the fen. We have found Achaeta spp. not only at Čertoryje but also at other grassland sites in the White Carpathians (unpubl. data), while not a single specimen was encountered at Výzkum. Probably Achaeta species were missing there because of their high sensitivity to physical soil disturbance and they have not yet immigrated into the study plots. Buchholzia spp., present at Čertoryje, are known to occur also in disturbed urban soils; we have no explanation for their absence at Výzkum.

\section{ACKNOWLEDGEMENTS}

The study was supported by the Czech Science Foundation (grant No. 526/02/0036: Development of vegetation and soil fauna during restoration of species-rich meadows: directing succession by sowing mixtures of meadow plants) 
and the Czech Ministry of Education, Youth and Sports (grant No. 143100010: Spatial and temporal biodiversity dynamics of ecosystems in Central Europe). The staff of the Institute of Soil Biology (Academy of Sciences of the Czech Republic) and the Administration of the White Carpathians Protected Landscape Area provided most valuable logistic support.

\section{REFERENCES}

Bezděčka, P. \& Jongepier, J. W. 2002. Bílé Karpaty. In Chráněná území ČR, II. - Zlínsko (Mackovčin, P. \& Jatiová, M., eds.), pp. 243-334. AOPK ČR \& Ekocentrum Brno, Praha.

Didden, W. A. M. 1993. Ecology of terrestrial Enchytraeidae. Pedobiologia, 37, 2-29.

Graefe, U. \& Schmelz, R. M. 1999. Indicator values, strategy types and life forms of terrestrial Enchytraeidae and other microannelids. Newsl. Enchytraeidae, 6, 59-68.

Kasprzak, K. 1986. Enchytraeids (Oligochaeta, Enchytraeidae) of the Little Carpathians. In The Soil Fauna of the Little Carpathians. Results of Research Program MAB, Project No-2 (Nosek, J., ed.), pp. 71-75. Slovak Academy of Sciences, Institute of Experimental Biology and Ecology of the Centre for Biological Sciences, Bratislava.

Kobetičová, K. \& Schlaghamerský, J. 2003. On the efficiency of three schemes of enchytraeid wet funnel extraction. Newsl. Enchytraeidae, 8, 25-31.

Schlaghamerský, J. 2005. The community of small annelids (Enchytraeidae, Tubificidae, Aeolosomatidae) in the first phase of meadow restoration on arable land. In Contributions to Soil Zoology in Central Europe I (Tajovský, K., Schlaghamerský, J. \& Pižl, V., eds.), pp. 127-132. ISB AS CR, České Budějovice.

Tajovský, K., Pižl, V., Starý, J., Balík, V., Frouz, J., Schlaghamerský, J., Háněl, L., Rusek, J. \& Kalčík, J. 2005. Development of soil fauna in meadows restored on arable land: initial phases of successional development. In Contributions to Soil Zoology in Central Europe I (Tajovský, K., Schlaghamerský, J. \& Pižl, V., eds.), pp. 181-186. ISB AS CR, České Budějovice.

\section{Väikeste rõngusside (Enchytraeidae, Tubificidae, Aeolosomatidae) kooslus neli aastat tagasi põllu asemele taastatud niidul, võrreldes põlise niiduga}

\section{Jiř́i Schlaghamerský ja Klára Kobetičová}

On uuritud väikeste rõngusside kooslusi katselappidel: põllu asemele taastataval niidul ja põlisel niidul. Usside arvukus oli madalaim endisel põllul, kuhu oli külvatud kohalike taimede seemneid; kõrgeim heintaimede isekülvist taastuval niidul ja kaubandusliku seemnesegu külvi puhul. Viies katseaasta (2003) oli põuane ja arvukus kõigil katselappidel ning ka lähedasel põllul väga madal. Kokku leiti katsealadelt 17 Enchytraeidae, 1 Tubificidae ja 2 Aeolosomatidae liiki; põliselt niidult vastavalt 22,1 ja 1 . Liigiline koosseis oli mõlemal pool üsna ühesugune. 